\title{
Active Restoration Initiates High Quality Forest Succession in a Deforested Landscape in Amazonia
}

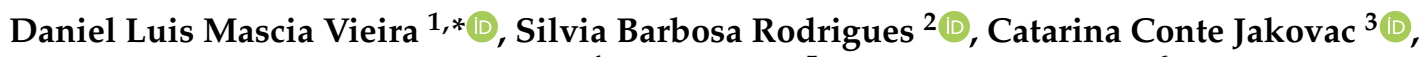 \\ Gustavo Paiva Evangelista da Rocha ${ }^{4}$, Fagno Reis ${ }^{5}$ and Augusto Borges ${ }^{6}$ \\ 1 Embrapa Recursos Genéticos e Biotecnologia, Parque Estação Biológica, PqEB, Av. W5 Norte (Final), \\ Brasília 70770-917, DF, Brazil \\ 2 Departamento de Ecologia, Instituto de Ciências Biológicas, Universidade de Brasília, \\ Brasília 70919-900, DF, Brazil; silviabrodri@gmail.com \\ 3 International Institute for Sustainability, Estrada Dona Castorina, 124, Rio de Janeiro 22460-320, RJ , Brazil; \\ catacj@gmail.com \\ 4 Tikré Brasil Soluções Ambientais, Rua Almery de Paiva 255, Catalão 75702-390, GO, Brazil; \\ gpe.rocha56@gmail.com \\ 5 Cooperativa de Produtores Rurais do Observatório Ambiental Jirau (COOPPROJIRAU), Rua Pitomba, \\ 1 Quadra B1, Nova Mutum Paraná 76842-000, RO, Brazil; fagno.reis@coopprojirau.com.br \\ 6 Energia Sustentável do Brasil S.A. (ESBR), Rodovia BR-364, KM 824, Porto Velho 76840-000, RO, Brazil; \\ augusto.borges@esbr.com.br \\ * Correspondence: daniel.vieira@embrapa.br
}

Citation: Vieira, D.L.M.; Rodrigues, S.B.; Jakovac, C.C.; da Rocha, G.P.E.; Reis, F.; Borges, A. Active Restoration Initiates High Quality Forest Succession in a Deforested Landscape in Amazonia. Forests 2021, 12, 1022. https://doi.org/10.3390/f12081022

Academic Editor: Pil Sun Park

Received: 7 June 2021

Accepted: 26 July 2021

Published: 31 July 2021

Publisher's Note: MDPI stays neutral with regard to jurisdictional claims in published maps and institutional affiliations.

Copyright: (c) 2021 by the authors. Licensee MDPI, Basel, Switzerland. This article is an open access article distributed under the terms and conditions of the Creative Commons Attribution (CC BY) license (https:// creativecommons.org/licenses/by/ $4.0 /)$.

\begin{abstract}
Amazonia is well known for its high natural regeneration capacity; for this reason, passive restoration is normally recommended for the recovery of its degraded forests. However, highly deforested landscapes in southern Amazonia require active restoration. Since restoration methods can shape the quality and speed of early forest recovery, this study aimed to verify how active restoration pushes sites stably covered with exotic grasses towards forest recovery. We evaluated early forest succession at active restoration sites, i.e., soil plowing, direct seeding of pioneer species, and seedling stock planting at low density. We analyzed forest structure, diversity, and species composition in two age classes, $0.5-3.5$ and $4.5-7.5$ years old. As reference, we evaluated sites able to naturally regenerate in the same region. We sampled 36 active restoration and 31 natural regeneration sites along the Madeira River, southern Amazonia. Active restoration triggered succession to similar or higher levels of forest structure than sites where natural regeneration was taking place. The most dominant species did not overlap between active restoration and natural regeneration sites. The overall composition of species was different between the two restoration methods. Dominant species and size class distribution show that active restoration is performing successfully. Soil preparation combined with a high availability of seeds of pioneer trees resulted in a high stem density and basal area of facilitative pioneer trees. Planted seedlings added species diversity and increased density of large trees. Interventions to increase the odds of natural regeneration can be effective for non-regenerating sites in resilient landscapes.
\end{abstract}

Keywords: secondary succession; assisted natural regeneration; regeneration mechanisms

\section{Introduction}

Natural regeneration can be the most cost-effective method for tropical forest restoration [1]. Throughout the world, tropical forests are recovering after being deforested and replaced for pasture and agriculture [2]. In fact, when natural regeneration capacity is high, active restoration can hinder or alter the successional trajectory already taking place [3]. However, even in Amazon forests, known for its high capacity of naturally regenerating and recovering biomass [4], succession may be arrested depending on the intensity and length of previous land use [5-7]. In such cases, assisted natural regeneration or active restoration are recommended $[2,5,8]$. 
In southern Amazonia, intensive agriculture and pastures, which involves annual soil revolving and application of herbicides, have dominated the landscape [9]. Through the reduction of forest cover and the elimination of local sources of regeneration (e.g., soil seed and sprouts bank) these landscapes have lost, or suffered severe reductions of, their potential for natural regeneration [5,8]. Introduced African grasses, mostly Urochloa spp., dominate these pastures and constrain seedling establishment $[5,10]$. In these cases, where natural regeneration does not initiate within a few years, active restoration is suggested [3,11].

Even if two or more methods are successful in restoring a site, each one leaves its own footprints on the recovery trajectory $[8,11,12]$. For example, although seedling planting restoration accelerates canopy closure and facilitates natural regeneration it also promotes a homogeneous dense canopy [11] that can hinder recruitment of early successional species [13]. In contrast, unassisted natural regeneration leads to a heterogeneous forest structure because of the heterogeneity of soil types, varying densities of invasive species, and random timing of species colonization. However, also in sites with high potential for natural regeneration, a monodominant canopy can be formed by native aggressive species [1,7]. In direct seeding of native species at high densities, another active restoration method, the canopy closes rapidly by the proximity of the stems [8], but the initial species composition is biased towards species adequate for seed and seedling production [12] Natural regeneration and active restoration will often result in succession communities with different species composition because of the restrictions imposed by seed availability, germination efficiency, and survival in active plantings [12,14], which might potentially conduce to divergent successional trajectories.

In this study we aim to understand how active restoration can put exotic grasses dominated and non-resilient sites on the path to recovery. We compared early successional trajectory of active restoration sites with naturally regenerating sites, as reference. In this study area, active restoration is applied to sites without natural regeneration, and natural regeneration is applied to sites where natural regeneration is occurring. Active restoration consists of a mix of interventions: soil preparation, control of invasive grasses, seedling planting, and direct seeding of native species. We hypothesized that vegetation structure and species richness will be more developed in active restoration than natural regeneration, because the former (i) eliminates grasses, a major tropical forest recovery obstacle [15]; (ii) improves seedling emergence of pioneer tree seeds from the seed bank and seed rain by providing full sun and uncompact soils $[8,16]$; and (iii) adds individuals and species from the onset of the restoration, by directly seeding and seedling planting [14]. We also hypothesized that species composition differs between the restoration methods, because natural regeneration sites start with an assemble of recruiting species and have not been subject to any intervention, while active restoration sites start without natural regeneration and have been submitted to interventions that stimulate the establishment of a larger pool of species. Active restoration would be more predictable than natural regeneration, because non-regenerating sites are more homogeneous, and the interventions are standardized.

\section{Methods}

\subsection{Study Area and Restoration Interventions}

The study sites are located along the Madeira River, south of the Jirau Hydroelectric Reservoir, in the Rondônia State, Brazil. The most common vegetation type in the study area is terra-firme forests, which occupies well-drained, nutrient-poor soils [17]. The forests were cleared in the 1970s for livestock pastures, resulting in sites dominated by the productive African grass Urochloa brizantha (see Rocha et al. [18] for more details). Pastures in the region are generally intensively managed using herbicides, mowing, and prescribed burning for pasture renovation and elimination of non-pasture plants regeneration (i.e., natural forest regeneration). Less intensified pastures are left to fallow for a few years and then renewed, a process that can be repeated multiple times. Old-growth and secondary forests cover $37 \%$ of the landscape in the study area [18]. 
The restoration sites are located within 30 to $100 \mathrm{~m}$ of the maximum flooding level over ca. $100 \mathrm{~km}$ along the Madeira River. These restoration sites are designated to protect the margins of the reservoir, in compliance with Brazilian environmental legislation. The restoration project uses an adaptive restoration plan, where the choice for the restoration method depends on a diagnosis of the potential for natural regeneration of each site. This is a practice to reduce costs and increase restoration success [19]. The presence of abundant natural regeneration previous to any management, mostly dominated by Vismia spp., indicated the potential for using natural regeneration as the restoration method. In sites where no or very few trees were found regenerating naturally, active restoration strategies were used.

Natural regeneration (NR) data was extracted from a study conducted in the same riparian buffer. In 2013, Rocha et al. [18] studied abandoned pastures after 0-15 years of forest succession (fallow age provided from Landsat imagery classification). We selected 31 of those sites to ensure the same age range of active restoration sites.

Active restoration (AR) was carried out during the years 2012-2018 in 36 sites that were covered with African pasture grasses and had low or no natural regeneration of forest species. Active restoration implemented in 14 sites before 2015 was based only on seedling plantings (Active SP). Over time and with the accumulated experience, we identified the possibility to reduce costs by using less seedlings per hectare and directly seeding other species. After 2015, active restoration was implemented in 22 sites using seedling planting and direct seeding (Active SP+DS). These sites were sampled between June and August 2019.

In Active SP sites (4.5-7.5 y-old in 2019), seedling spacing varied according to the density of naturally regenerating trees. In sites with very low or no natural regeneration $\left(<400\right.$ tree recruits $\cdot \mathrm{ha}^{-1}$ ), seedlings were planted at a $3 \mathrm{~m} \times 2 \mathrm{~m}$ spacing; in sites with 400-1000 tree recruits ha $^{-1}$, the spacing was $5 \mathrm{~m} \times 5 \mathrm{~m}$ or $5 \mathrm{~m} \times 4 \mathrm{~m}$. Despite the variation in seedling spacing, all Active SP sites were considered similar. We compared the structural attributes between narrow and wide spacing, grouping the sites with age between 4.5 and 7.5 years, and found no statistical difference for all vegetation attributes but absolute richness, where higher seedling density resulted in 41 species, while wide spacing sites had 35 species on average $\left(t\right.$-test ${ }_{(\mathrm{n}=12)}$; basal area: $t=2.06 ; p=0.091$; canopy height: $t=1.91 ; p=0.080$; density of trees: $t=-0.24 ; p=0.812$; density of seedlings: $t=0.40$; $p=0.694$; richness: $t=2.35 ; p=0.038$; rarefied richness: $t=1.51 ; p=0.156$ ).

Active SP+DS sites (0.5-3 y-old sites) had seedling planting at $5 \mathrm{~m} \times 5 \mathrm{~m}$ spacing and additionally were directly seeded by manual broadcasting over the entire site. A total of 33 species were seeded, with each site having between 5 and 15 species sowed using different amounts of seeds (Table A1). These 33 species were pioneer or heliophyte with availability of seeds in the area. Total seed mass and species composition varied among sites (Table A1).

In the active restoration sites, the following steps were executed: (i) a few days before planting the soil was harrowed at 20-30 cm depth with a tractor-driven disc harrow to remove exotic grasses; (ii) seedlings were planted manually following the spacing described above, and seeds were broadcasted (only in the Active SP+DS); (iii) during the first two years after planting, herbicide (glyphosate) was applied one to four times to control Urochloa grasses until the tree canopy could shade out the grasses. Herbicide application was also subject to a learning process. While in the oldest sites (7.5 y-old) herbicides were applied extensively over the entire area (just avoiding damaging the planted seedlings), in the younger sites, application was targeted to the grass tussocks.

Active restoration and natural regeneration sites were evenly distributed along the riparian buffer (Figure 1). 


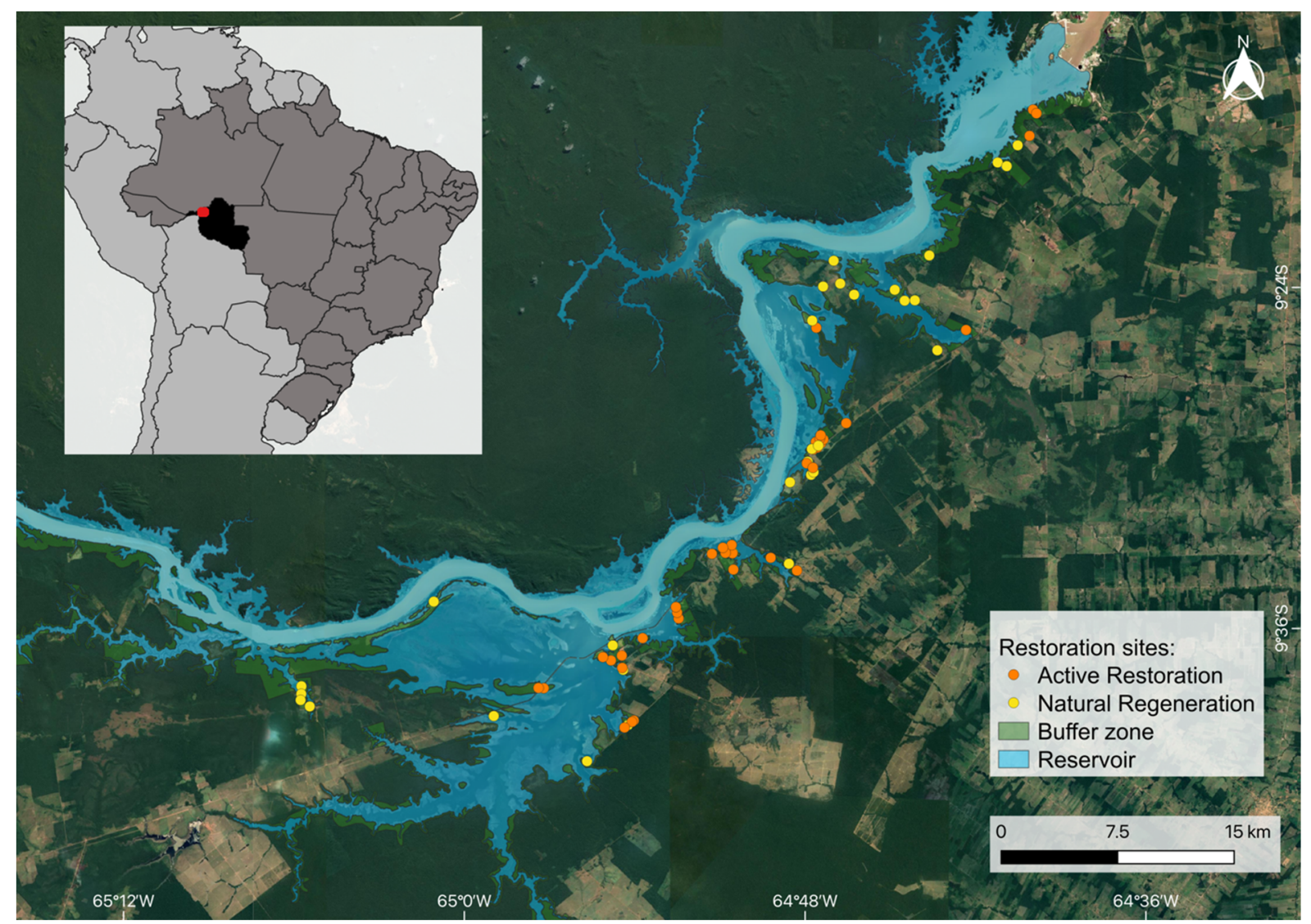

Figure 1. Active restoration and natural regeneration sites sampled in the buffer zone of the Jirau Hydroelectric Reservoir along the upper Madeira River, Rondônia State (Brazil).

\subsection{Sampling and Species Classification}

In NR sites, one circular plot with a $10 \mathrm{~m}$ radius was established on each site, totaling 31 plots (for a more detailed description, see Rocha et al. [18]). In each plot, all stems of tree species with height $>30 \mathrm{~cm}$ were identified and measured. Diameter of stems was measured with a digital caliper at ground level. From the available data, we separated trees (height $>2 \mathrm{~m})$ from seedling $(0.3 \mathrm{~m}<$ height $<2 \mathrm{~m})$ to perform comparative analyses. To calculate the diameter at breast height (DBH), we transformed the diameter at the base using the equation for secondary forest plants provided by Gehring et al. [20], which transforms D30 cm to DBH.

We sampled 36 restoration sites, ranging from 0.9 to 39.7 ha. Five $25 \mathrm{~m} \times 10 \mathrm{~m}$ plots were randomly allocated in each site, where trees (height $>2 \mathrm{~m}$ ) were measured. Seedlings $(0.3 \mathrm{~m}<$ height $<2 \mathrm{~m})$ were measured within five $25 \mathrm{~m} \times 4 \mathrm{~m}$ subplots nested along the longitudinal centerline of the plot. We identified seedlings and trees, and measured height $(\mathrm{H})$ and DBH of trees. Species were collected and identified with assistance of botanists of the herbarium of Embrapa Genetic Resources and Biotechnology (CEN).

Species and stems were classified as "planted seedling", "direct seeded or natural regeneration" or as "natural regeneration". Stems were identified as "planted seedlings" in the field by their systematic location and species pool. It was not possible to distinguish between direct seeded- and natural regeneration-stems because direct seeded species were also (i) from the regional pool that normally colonize restoration sites or (ii) from seeds dispersed from adult trees planted as seedlings. Therefore, the class that included the direct-seeded species was named "direct seeded or natural regeneration". We used the list of seeded species for each site, and when a species was seeded it was classified as "direct seeding or natural regeneration" for that site. The non-planted species in each site were assigned to "natural regeneration". 


\subsection{Data Analysis}

We calculated basal area $\left(\mathrm{m}^{2} / \mathrm{ha}\right)$, density of trees and seedlings (ind /ha), and canopy height $(\mathrm{m})$. The basal area was calculated including all tree stems (height $>2 \mathrm{~m}$ ). The canopy height was defined as the upper decile of the height of trees sampled in each site. We calculated the rarefied species richness per 25 individuals, which was the lowest number of individuals of all plots, to allow direct comparisons between active restoration and natural regeneration. The comparisons between active restoration and natural regeneration were made separately for younger and older sites in order to consider the two different methods of active restoration: $\mathrm{NR} \times$ Active $\mathrm{SP}$ (for 4.5-7.5 y-old sites) and $\mathrm{NR} \times$ Active SP+DS (for 0.5-3.5 y-old sites). We performed ANCOVAs to assess difference in vegetation attributes between the two restoration methods, considering age as a co-variable. Density of trees and seedlings were square-root and log-transformed, respectively, to meet model assumptions.

To test if species composition differs between AR and NR sites and if AR is more predictable (homogeneous), we applied a distance-based redundancy analysis (db-RDA) [21]. We included age (as continuous variable) and method (AR and NR) as predictors of the species composition. Then, we used ANOVA to test the significance of the overall model and constraint variables. The distance index between pairs of sites used was the Chao-Jaccard on the abundance matrix. We found no spatial autocorrelation of species composition when applying a Mantel's test.

We described AR and NR sites in relation to the 10 most dominant species, separately for younger and older sites in order to consider the two different methods of active restoration.

To evaluate how restoration unfolds in active restoration sites, we estimated the relative contribution of "planted seedlings", "seeded seeds or natural regeneration", and "natural regeneration" on the tree community over time.

All analyses were conducted in R version 3.6.2 (R Core Team 2019), using vegan and stats packages.

\section{Results}

At the NR sites, we recorded 2063 trees (in $0.85 \mathrm{ha}$ ) and 1125 seedlings (in $0.97 \mathrm{ha}$ ), from 45 families (with 2 non-identified stems) and 183 species. At the AR sites, there were 8794 trees (in 4.37 ha) and 6280 seedlings (in 1.8 ha), from 36 families and 155 species (with 15 non-identified stems; Table A2).

Active restoration triggered a structural forest succession to the same or higher levels of sites where natural regeneration was occurring (Figure 2). On average, basal area was $3.49 \mathrm{~m}^{2} / \mathrm{ha}$ for AR and $3.27 \mathrm{~m}^{2} / \mathrm{ha}$ for NR at younger sites, and $8.86 \mathrm{~m}^{2} / \mathrm{ha}$ and $9.35 \mathrm{~m}^{2} / \mathrm{ha}$ at older sites. Canopy height was $4.69 \mathrm{~m}$ for AR and $4.36 \mathrm{~m}$ for NR at younger sites, and $7.20 \mathrm{~m}$ and $7.35 \mathrm{~m}$ at older sites. Tree density was not different between AR and NR in both age classes. Seedling density was almost two times greater in AR SP+DS sites (mean of 2003 ind/ha) than in NR sites (mean of 1134 ind/ha), and six times higher at older ages (AR SP = 5927 ind /ha; NR = 978 ind /ha). Rarefied richness was higher in younger AR PS+SD (9.88 species per 25 stems) than in younger NR (6.66 species), as well as absolute richness, which was 27.5 in AR PS+SD and 9.66 species in NR on average. At older ages, rarefied and absolute richness was not significantly different between AR and NR, as AR did not increase, and NR increased relative to younger sites. 


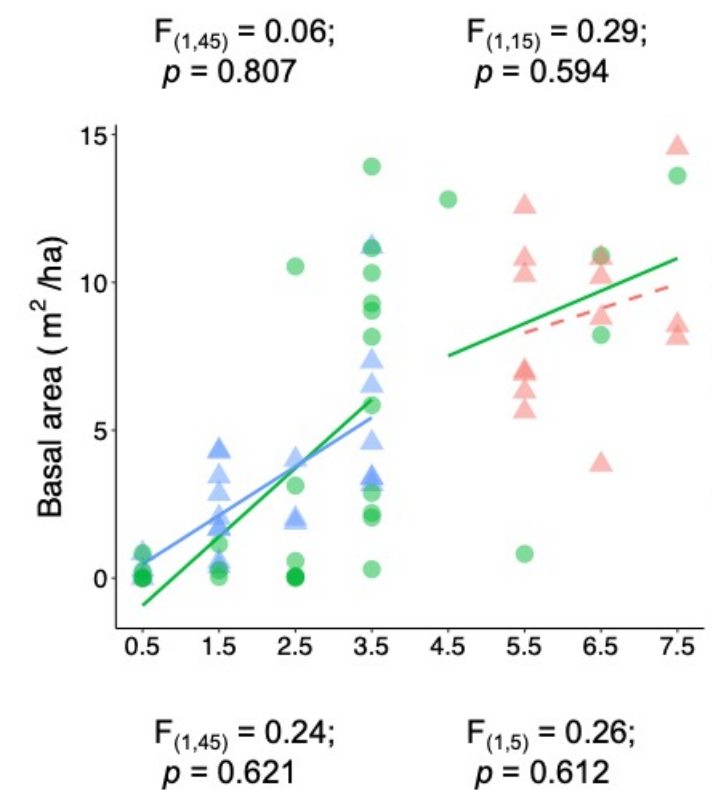

$$
\begin{array}{ll}
\mathrm{F}_{(1,45)}=0.34 ; & \mathrm{F}_{(1,15)}=0.36 ; \\
p=0.562 & p=0.556
\end{array}
$$
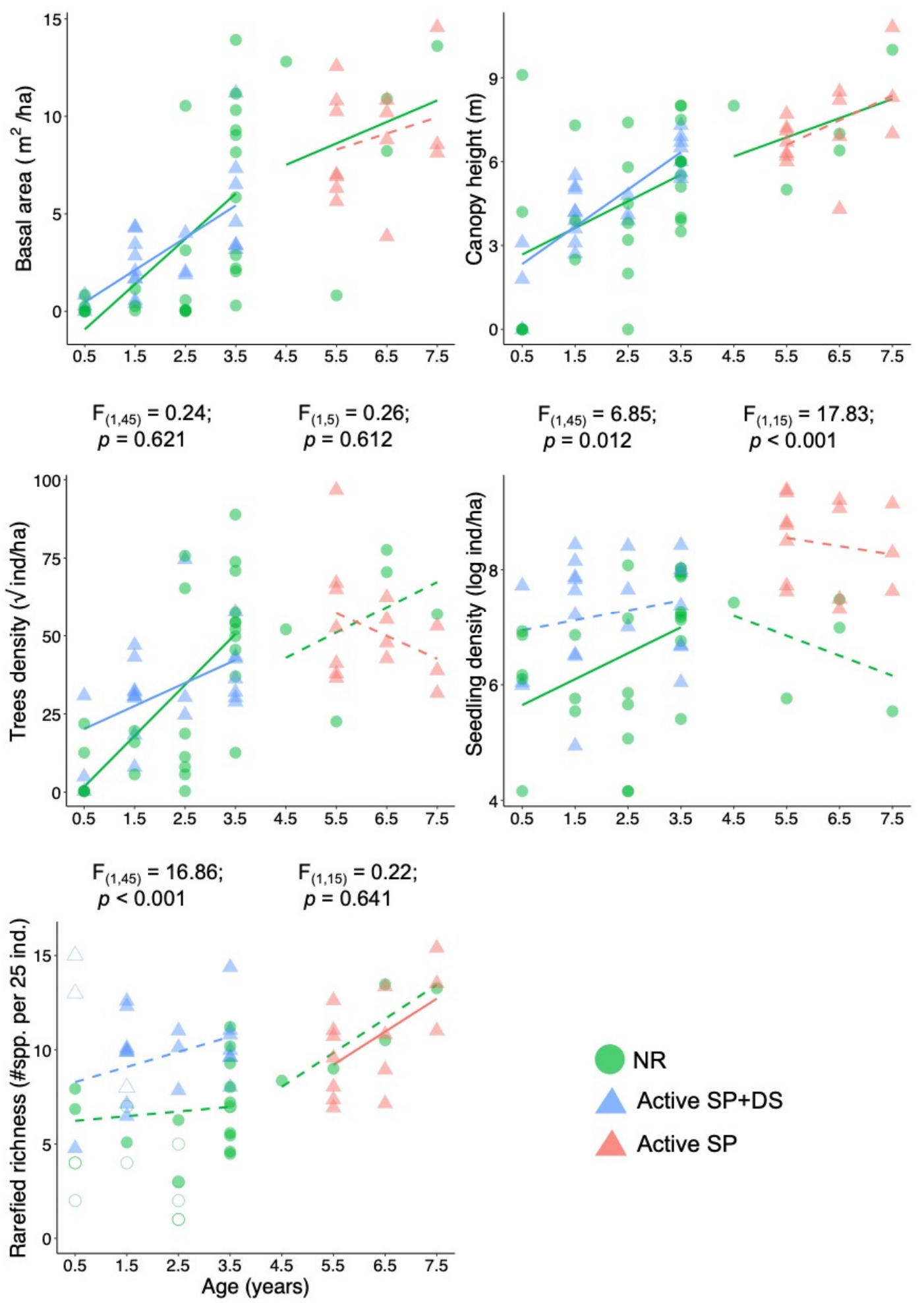

NR

Active SP+DS

Active SP

Figure 2. Forest structure attributes of vegetation community in active restoration and natural regeneration sites, located south of Jirau Hydroelectric Reservoir, along the upper Madeira River. Dots and triangles represent sampled sites. Regression lines describe the trajectories of the attribute over time divided in two blocks: 0.5-3.5 y-old sites, where active restoration included seedling planting and direct seeding of pioneer species (AR SP+DS) and 4.5-7.5 y-old sites, where it included only seedling plantings (Active SP). In the rarefied richness plot, non-filled shapes represent sites with less than 25 individuals sampled and absolute richness values were used in the plot, but not considered for the regression fit. 
Active restoration had higher size-structure heterogeneity than natural regeneration, increasing the density of recruits ( $<2 \mathrm{~m}$ high trees; Figure 2$)$, reducing intermediary sizeclasses and increasing density of large stems ( $>25.1 \mathrm{~cm} \mathrm{DBH}$; Appendix A: Figure A1).

The most dominant species were different between AR and NR (Figure 3). NR showed strong dominance of the same species over time. Vismia sp. was responsible for $58 \%$ of the total basal area in younger sites and $45 \%$ in older sites of NR (Figure 3). The younger AR sites had lower dominance, with ten species being responsible for $62 \%$ of the total basal area (Figure 3). The five most dominant species were the fast growing and shortlived Senna alata, Trema michrantha, Solanum spp., Muntingia calabura, Cecropia purpurascens, and the 6-10 most abundant were Psidium guajava (long-lived small tree), Cochlospermum orinocense and Cecropia membranacea (fast growing short-lived), Inga edulis (planted) and Ceiba sumauma (planted). In older AR sites, the dominance was even lower, with $55 \%$ of the basal area composed by the ten most abundant species, which were mostly non-planted naturally regenerating species (Figure 3).
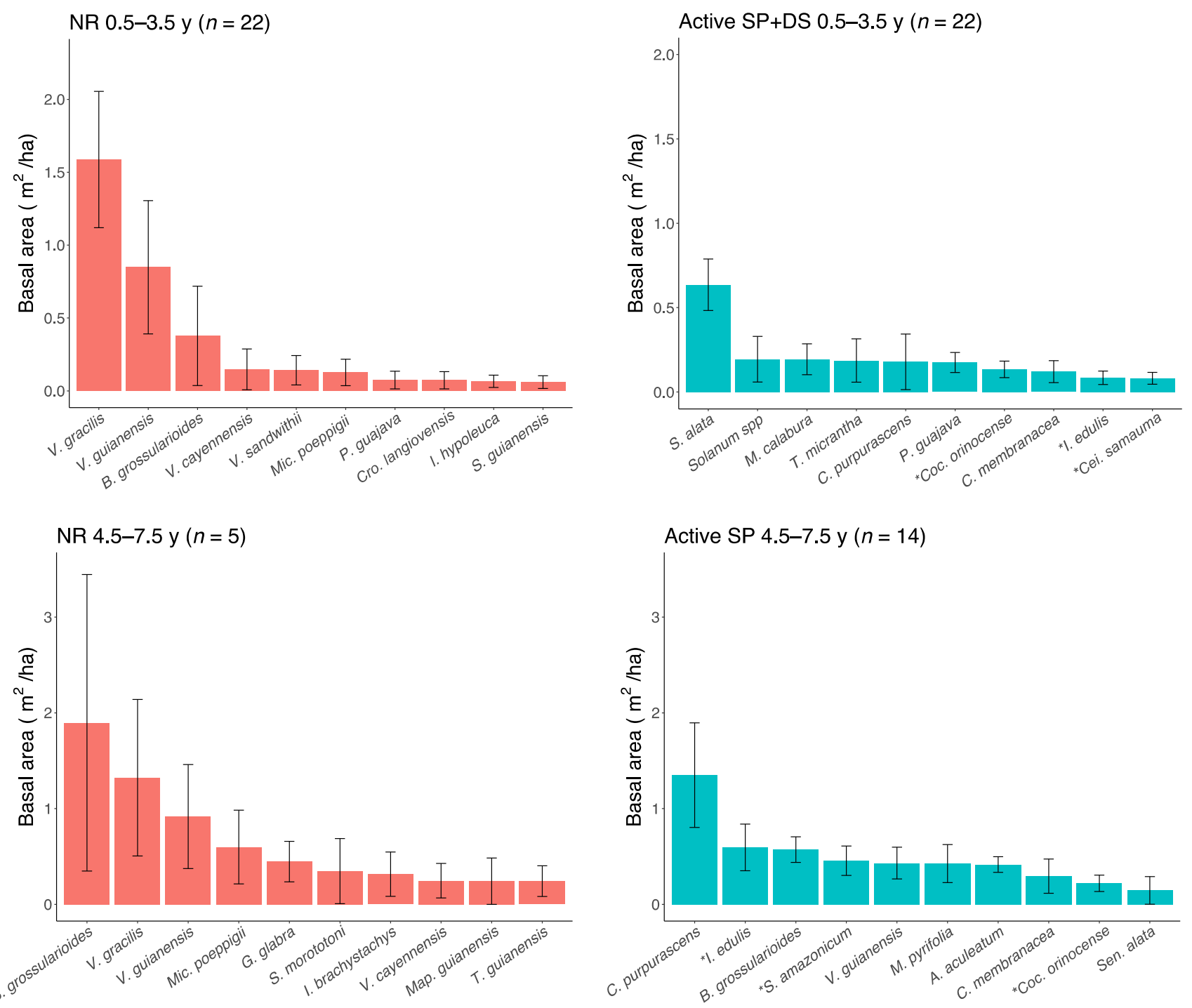

Figure 3. Basal area (mean \pm standard error) of the ten most dominant species sampled in sites of natural regeneration (31) and active restoration (36) located in the south of Jirau Hydroelectric Reservoir, along the upper Madeira River. For 0.5-3.5-y-old sites, active restoration included seedling planting and direct seeding of pioneer species (Active SP+DS) and for 4.5-7.5-y-old sites, it included only seedling plantings (Active SP). Species with an asterisk $\left(^{*}\right)$ were planted as seedlings in active restoration sites. 
The db-RDA explained $28.6 \%\left(\mathrm{R}^{2}\right)$ of the variation in species composition and the model was significant (overall model: $\mathrm{F}_{2,64}=8.01 ; p=0.001$. Figure 4). First axis (CAP1) explained $24.1 \%$ and was mainly driven by the restoration method (AR or NR). The second axis (CAP2) explained an additional $4.5 \%$, age being the most important variable. The effects of method and age on species composition were significantly different from random. The restoration method explained $23 \%$ of the variation in species composition $\left(\mathrm{F}_{1,64}=2.79\right.$; $p=0.006)$ and age explained only $3 \%\left(\mathrm{~F}_{1,64}=13.22 ; p=0.002\right)$.

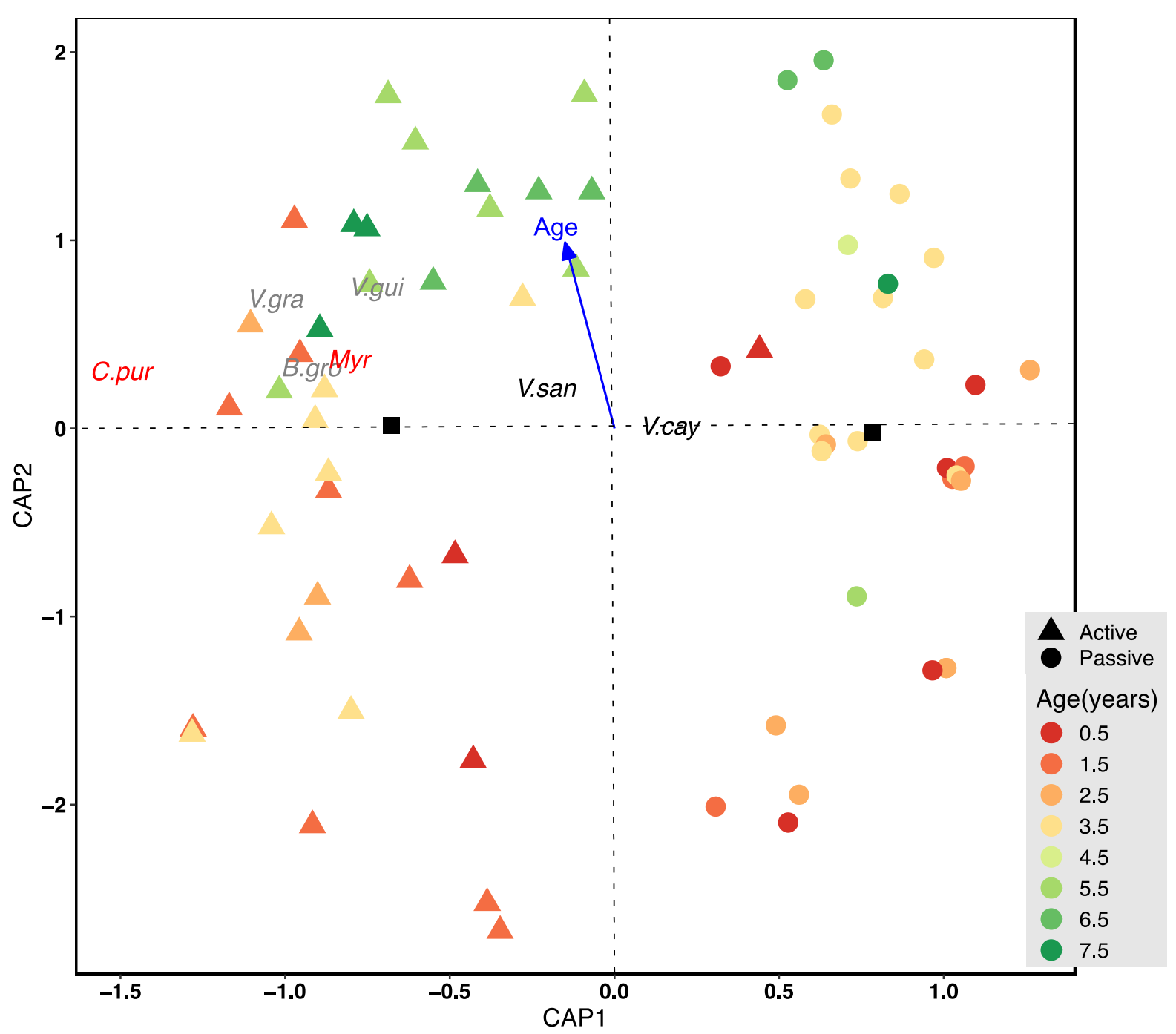

Figure 4. Biplot of the db-RDA of the species composition in 36 active restoration sites (triangle) and 31 natural regeneration sites (circles) located south of Jirau Hydroelectric Reservoir along the upper Madeira River. Black squares represent the centroids of the restoration methods. Abbreviations are the names of the most abundant species sampled in active restoration sites (in red), natural regeneration sites (in black), and both methods sites (three grey names), B.gro: Belluccia grossularioides; C.pur: Cecropia purpurascens; Myr: Myrcia sp.; V.cay: Vismia cayennensis; V.gra: Vismia gracilis; V.gui: Vismia guianensis; V.san: Vismia sandwithii.

In active restoration sites, planted seedlings had a moderate contribution to basal area and stem density, reaching less than $30 \%$ of the basal area and $14 \%$ of the total stems in both AR SP+DS (younger) and AR SP sites (older; Figure 5a,b). Planted seedlings accounted for $42 \%$ of species richness in AR SP+DS, and for $25 \%$ in AR SP sites (Figure $5 c$ ). Natural regeneration dominated basal area, stem density, and species richness in active restoration sites (Figure 5). Direct seeding was applied only to 0.5-3.5-y-old sites. Seeded species, which could also be natural regeneration, contributed to $29 \%$ of the basal area, 
$24 \%$ of the stem density, and $9 \%$ of the species richness in AR PS+SD sites, where it was applied (Figure 5).
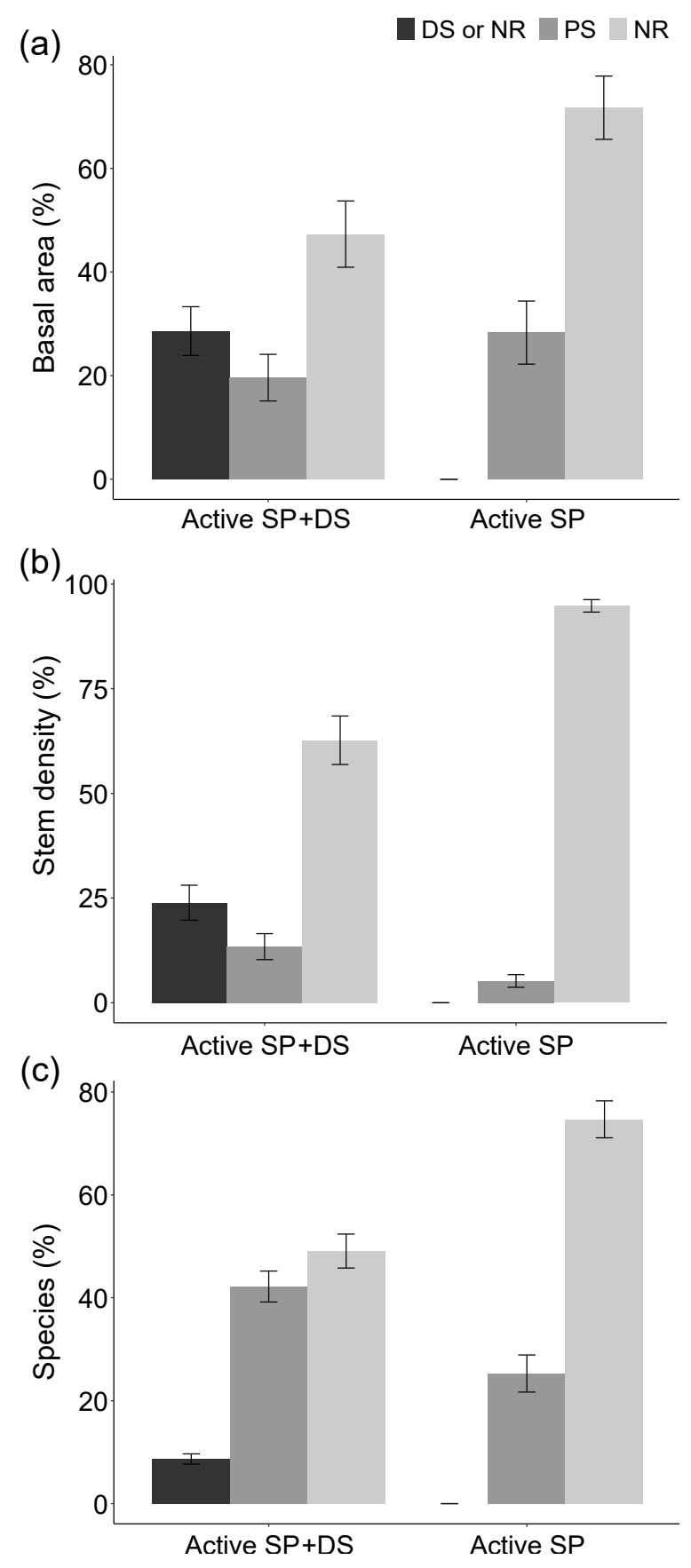

Figure 5. Contribution (mean percentage \pm standard error) of planted seedlings (PS), direct seeding or natural regeneration (DS or NR), and natural regeneration (NR) to the (a) basal area, (b) stem density, and (c) species richness of active restoration sites. For 0.5-3.5-y-old sites, active restoration included seedling planting and direct seeding of pioneer species (AR SP+DS) and for 4.5-7.5-y-old sites, it included only seedling plantings (Active SP). A total of 36 active restoration sites were sampled in the south of Jirau Hydroelectric Reservoir along the upper Madeira River.

\section{Discussion}

Our results showed that active restoration practices triggered forest succession on sites formerly dominated by African grasses that had weak or no natural regeneration. Forest structure in active restoration sites developed at a similar rate as sites naturally 
regenerating, therefore subject to passive restoration. Stem density and rarefied species richness were higher in active restoration sites than in natural regeneration sites, due to seed and seedling addition and, especially, to the stimulus of new stems and species recruitment. Species composition in active restoration sites included a shared dominance of short-lived pioneer trees, typical of less disturbed natural regeneration sites, in opposition to the Vismia-dominated natural regeneration sites [7].

\subsection{Active Restoration Is a Matter of Eliminating Regeneration Filters}

The success of the active restoration was explained by preparing a loose soil, free from exotic grasses, with small furrows and mounds, associated with a high availability of seeds of pioneer trees. That resulted in high stem density and basal area of pioneer trees, as seen in the older sites with no direct seeding intervention. Species planted, either through direct seeding or planted seedlings, contributed little to the species richness (25-50\%), and basal area (28-48\%). In an experiment designed for decoupling the effects of soil preparation and seed and seedling addition, stem density was similar in plots with only soil preparation and those with soil preparation and seeding or seedling planting [5]. These results show that the barrier to natural regeneration in this landscape is not seed availability, but the local conditions for germination and establishment, and suggest that soil preparation and grass control might be more important than introducing species through planting.

In the restoration project studied here, direct seeding has been a safety strategy for sites that do not have enough seed density from seed rain or seed bank. Restorationists apply it to all active restoration sites without seeing the density of new seedlings after soil preparation, as it needs to be set during the first month after soil harrowing, which is the window of opportunity for germination and establishment. However, in landscapes with even lower forest cover and lower abundance of pioneer trees in the agricultural matrix, direct seeding might be necessary. Direct seeding can be a low-cost restoration strategy if it is based on common pioneer species that are abundant and easy to collect, and if labor for seed harvesting is available. When using a larger diversity of species and including old-growth forest species with recalcitrant seeds, costs might raise.

Forest landscape cover affects the effect size of the active restoration. Active restoration is more necessary to guarantee restoration success in landscapes with low forest cover [22]. In the studied landscape, planted species promoted higher species richness in the restored sites only in the first few years. In the older sites, species colonization happened in natural regeneration sites to a point of no difference in species richness. We suggest that with the forest cover in the studied landscape of Amazonia (37\% [18]), restoration intervention should focus on structuring a tree canopy in order to facilitate natural colonization. At the southern border of Amazonia, in a landscape with $18 \%$ forest cover on average, non-planted species colonize sites at an average rate of 0.4 species/year for 10 years after direct-seeding restoration (considering a plot size of $500 \mathrm{~m}^{2}$ for adults, $100 \mathrm{~m}^{2}$ for saplings and $25 \mathrm{~m}^{2}$ for seedlings [8]). Thus, even within highly deforested landscapes, active interventions will be more efficient if designed for triggering natural regeneration, than planting an assembled forest.

Differently from the southern Amazonia, other restored tropical forests are sustained by the planted seedlings [12-14,23]. In the Atlantic Forest, $97 \%$ of the above ground biomass in 7-20-year-old active restoration sites were from planted trees [14], evidencing that natural regeneration was scarce. Yet, in older (up to 53 years) active restoration sites in the Atlantic Forest, there is an increase of species- and life-form diversity, becoming similar in structure and species composition to old-growth forests [24].

\subsection{Active Restoration and Naturally Regenerating Forests in Amazonia}

The active restoration sites of up to 7.5 years old were dominated by different species when compared with the, formerly more resilient, natural regeneration sites. Natural regeneration sites were dominated by Vismia spp., responsible for $59 \%$ and $45 \%$ of basal area in younger and older sites, respectively. After active restoration, sites with a stable $U$. brizantha cover were dominated by S. alata, Cecropia spp., Solanum spp., M. calabura, and T. michranta in the first three 
years and then by C. purpurascens. The dominance of Cecropia spp. makes actively restored sites more similar to highly resilient sites of Amazon forests than to the Vismia-dominated sites. In other parts of Amazonia, sites that have low resilience because they were subject to decades of exotic grasses cultivation and frequent fires to prevent forest recovery, tend to be dominated by Vismia spp. Sites that were subjected to milder use and thus retained higher resilience tend to be dominated by Cecropia spp. and to be more biodiverse [6,7].

The cause for the impoverished regenerating community at Vismia-dominated sites is attributed to the degradation of soil quality, loss of sprouting ability of most species, and non-facilitative life-history traits of Vismia spp. [6,25]. In this restoration project (see also [5]), we were able to verify that preparing soil and eliminating $U$. brizantha cover triggered an early community dominated by Cecropia spp. Thus, our study adds that the exotic grass cover is a strong filter that affects compositional trajectory. Removing the grass cover is a low-cost intervention that allows for a healthier succession. However, further studies are needed to assess if the early community facilitated by the intervention advances in a similar way to the highly resilient Cecropia-dominated sites in Central Amazonia. Soil conditions could differ between AR and NR sites prior to the restoration because AR sites had higher pasture intensification, with fertilizer and herbicide application and dense grass cover.

Active restoration sites were remarkably different from natural regeneration sites in respect to species composition. Natural regeneration sites were dominated by Vismia spp., species that maintain dense stem populations in heavily used pastures by resprouting [7]. Self-thinning in Vismia-dominated secondary forests is slower than in more resilient forests, because Vismia spp. have a long life-cycle and because they maintain the recruitment of new individuals by sprouting [26]. This resulted in less tall trees and less recruitment of non-planted species, compared to active restoration sites.

In active restoration sites, initial recruitment originated from short life-cycle trees, such as Solanum spp., T. michrantha, and S. alata. In high stem density sites, these species died after ca. 3 years, opening space for new recruitment. Solanum spp. is a genus of shrubs and small trees that colonize active pastures [27] and, in our study, it colonized sites with prepared soil. Solanum spp. attract high densities of bats that bring Cecropia spp. seeds to the site [28]. Consequently, Cecropia spp. emerged. This extremely fast compositional change promoted higher size-structure heterogeneity, increasing density of recruits and reducing intermediary size-classes. In addition, planted seedlings developed into large trees $(>25.1 \mathrm{~cm} \mathrm{DBH})$ in active restoration sites.

\subsection{Active Restoration or Natural Regeneration?}

This study contributes to the understanding of how restoration methods can shape early trajectories of forest recovery. Our study does not allow recommending which one is more cost-effective, since active restoration was applied to sites stably covered with African grasses and natural regeneration was applied to sites where forest was naturally regenerating. Given the low levels of funding for restoration, a simple recommendation would be to use natural regeneration where the natural regeneration potential is high enough to trigger and maintain a successional trajectory [1,3]. However, different compositional trajectories $[6,7,25]$ and even more contrasting rates of structural development have been observed in natural regeneration [29], depending on the land use history. Variations are also observed in actively restored sites, due to different intervention methods [8,23,30,31]. Thus, a relevant question is if we can significantly improve secondary forests quality, for biodiversity, and carbon increment, with cost-effective interventions. We suggest that simple and cheap interventions directed at improving the potential for natural regeneration can be effective for non-resilient sites located in resilient landscapes.

Passive restoration might not be an option in some regions in southern Amazonia. In the state of Rondônia, there are municipalities with 15\% of forest cover, and landscapes with less than $5 \%$ of forest cover if we consider landscape sizes of $25 \mathrm{~km}^{2}$ (analyzed from Project MapBiomas Collection 4.1. www.mapbiomas.org.br (accessed on 22 June 2020)), a landscape size in which forest cover affects restoration success worldwide [22]. Southern Amazonia 
has the largest area demanding restoration in order to comply with Brazilian environmental laws [32]; sites will probably need active restoration or assisted natural regeneration.

\section{Conclusions}

Active restoration practices applied to sites that had no or low natural regeneration fostered the development of forest structure in a similar rate as sites that had higher potential for natural regeneration and which were subject to passive restoration. Interestingly, active restoration led to higher stem density and rarefied species richness than passive restoration sites, mainly because of the elimination of factors limiting natural regeneration and less so because of the species introduced through seeding or planting. The preparation of the soil previous to planting and the grass control during the first 2 years stimulated the natural regeneration of a diversity of species leading to higher diversity, and lower dominance than in the passive restoration sites. In landscapes where local conditions are more limiting to forest regrowth than seed dispersal from the surrounding landscape, active restoration practices should focus on eliminating the limitations to succession and consequently stimulating natural regeneration.

Author Contributions: D.L.M.V. conceptualized the research; G.P.E.d.R., F.R., and A.B. collected the data; S.B.R., D.L.M.V., and C.C.J. analyzed the data, interpreted the results, and contributed to writing. All authors read and approved the final manuscript.

Funding: Energia Sustentável do Brasil (ESBR) sponsored this work through a contract with Embrapa Genetic Resources and Biotechnology to plan and monitor the restoration of the Permanent Reserve of the Jirau Dam. The sponsor (ESBR) was not involved in the design of the study; data analysis, and interpretation; writing of the manuscript; nor in the decision to submit this article for publication.

Data Availability Statement: The datasets generated, analyzed, or both, during the current study are available in the ForestPlot repository, https:/ / www.forestplots.net (accessed on 20 August 2020).

Acknowledgments: Several workers from COOPPROJIRAU helped with the field survey. DLMV has a research grant from the National Council for Scientific and Technological Development (CNPq).

Conflicts of Interest: The authors declare that they have no competing interests.

\section{Appendix A. Supporting Information}

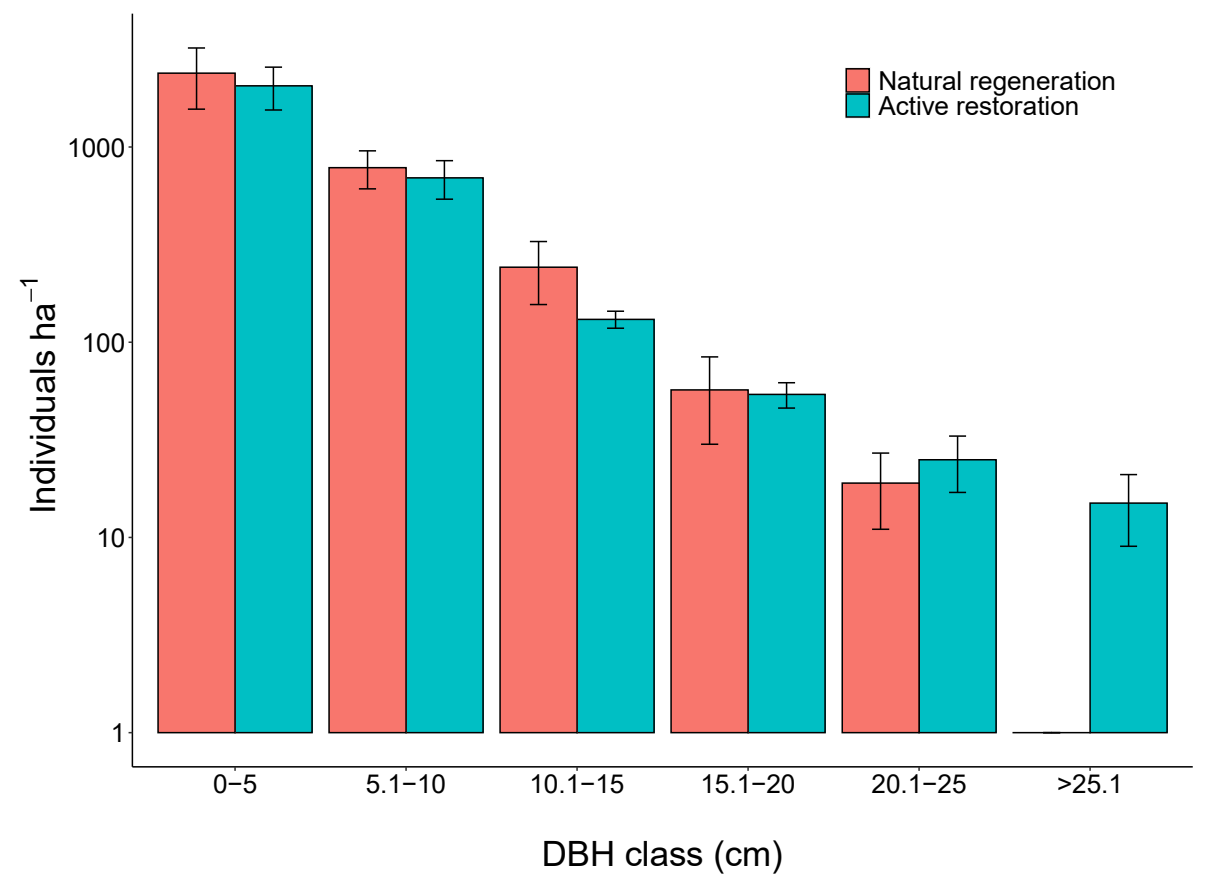

Figure A1. Diameter distribution in active and natural regeneration sites. 
Table A1. List of the 33 species used in direct seeding with indications of the amount of seeds (measured in kilograms) sowed in each active restoration site after 2015. Each site is named with its area ID and age at the moment of sampling (2019). Sites are located south of the Jirau Hydroelectric Reservoir, along the upper Madeira River.

\begin{tabular}{|c|c|c|c|c|c|c|c|c|c|c|c|c|c|c|c|c|c|c|c|c|c|c|}
\hline & & & & & & & & & & & Site- & & & & & & & & & & & \\
\hline & 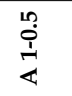 & $\begin{array}{l}\text { n? } \\
\dot{1} \\
\text { ஸे } \\
\text { ব }\end{array}$ & 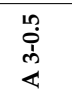 & $\underset{⿱ ㇒}{\stackrel{1}{+}}$ & 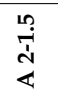 & कृ & 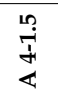 & 吕 & 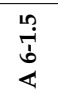 & $\begin{array}{l}\frac{10}{1} \\
\frac{1}{\Delta}\end{array}$ & 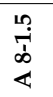 & « & 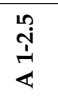 & $\begin{array}{l}10 \\
\text { ì } \\
\text { N } \\
\ll\end{array}$ & $\begin{array}{l}\text { ñ } \\
\text { ஸे } \\
\text { ஸे }\end{array}$ & $\begin{array}{l}\text { Ln } \\
\stackrel{9}{9} \\
\stackrel{+}{4}\end{array}$ & $\begin{array}{l}10 \\
\dot{p} \\
\dot{N} \\
\varangle\end{array}$ & 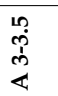 & $\begin{array}{l}n \\
\stackrel{n}{p} \\
\dot{+} \\
\varangle\end{array}$ & 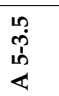 & $\begin{array}{l}10 \\
\text { p̧ } \\
0 \\
4\end{array}$ & $\begin{array}{l}\text { no } \\
\stackrel{p}{1} \\
\stackrel{1}{4}\end{array}$ \\
\hline Adenanthera pavonina & & & & & 2.4 & & 1.5 & & & & & & 2.6 & & & & & & & & & \\
\hline Anacardium occidentale & & & & & & & & & & & & & & & & 2.8 & & 1.8 & 1.4 & 4.0 & 3.0 & 0.9 \\
\hline Annona montana & & & & & & & & & & & & & & 2.1 & 3.2 & & & & & & & \\
\hline Apeiba tibourbou & 3.7 & 3.7 & & & & & & & & & & & & & & & & & & & & \\
\hline Bauhinia sp. & & & & & & & 1.7 & & & & & & & & & 1.5 & 0.1 & 1.6 & 1.8 & 1.9 & 0.8 & 0.6 \\
\hline Bellucia grossularioides & & & & & & & & & & & & & & & 2.7 & & & & & & & \\
\hline Bixa orellana & 15.1 & 15.1 & 11.8 & 4.0 & 2.5 & 1.0 & 1.9 & & & & & 2.0 & 0.5 & 5.0 & 11.2 & & & & & & & \\
\hline Byrsonima crassifolia & & & & & & & & & & & & & & 1.0 & 5.0 & & & & & & & \\
\hline Cecropia spp. & 1.1 & 1.1 & 2.8 & & & & & & 0.5 & 0.5 & & & & 1.3 & & 1.0 & 0.1 & 1.9 & 1.4 & 2.2 & 1.9 & \\
\hline Ceibasp. & & & & & 2.7 & & 0.6 & & & & & & 1.5 & & & & & & & & & \\
\hline Cochlospermum orinocense & 3.7 & 3.7 & 2.1 & & & & & & & & & & & & & & & & & & & \\
\hline Euterpe oleraceae & 1.2 & 1.2 & 1.2 & 12.1 & & 2.1 & 1.8 & & & & 0.5 & 7.0 & & & & & & & & & & \\
\hline Handroanthus avellanedae & & & & & & 0.9 & 0.4 & & & & & & & & & & & & & & & \\
\hline Handroanthus chrysotrichus & & & & 2.1 & 1.3 & 1.4 & & & & & & 0.5 & 0.3 & & & & & & & & & \\
\hline Himatanthus sucuuba & & & & & & & 0.7 & & & & & & & & & & & & & & & \\
\hline Hymenaea courbaril & & & & & & & & & & & & & & & & 2.0 & & 6.0 & 2.8 & 4.8 & 3.0 & \\
\hline Jenipa americana & & & & 3.1 & & & & 1.6 & 4.5 & 4.5 & & & & & & & & & & & & \\
\hline Não identificada & & & & & & & & & & & & 11.6 & & 6.6 & 10.4 & & & & & & & \\
\hline Ochroma pyramidale & 4.1 & 4.1 & & 3.9 & & & 0.8 & & & & & & & 2.7 & & & & & & & & \\
\hline Pachira sp. & & & & 1.7 & & & & & & & & & & & & & & & & & & \\
\hline Schizolobium amazonicum & 1.0 & 1.0 & & 4.1 & 3.0 & 1.2 & 1.7 & & & & 1.0 & 1.9 & 0.2 & & & 2.9 & & 5.7 & 2.9 & 6.5 & 4.9 & 2.6 \\
\hline Sclerolobium paniculatum & & & & 6.4 & 2.9 & 2.6 & 1.4 & & & & 0.5 & 5.0 & 1.3 & & & & & & & & & \\
\hline Senna alata & 5.5 & 5.5 & 4.5 & 4.8 & 4.1 & 2.2 & 2.1 & & & & 0.4 & 1.3 & 1.0 & & & 0.6 & 0.1 & 2.0 & 1.3 & 2.0 & 1.3 & 0.3 \\
\hline Solanum spp. & 48.1 & 48.1 & 19.9 & 1.0 & & & 1.2 & 1.6 & 4.5 & 4.5 & & 2.3 & & 3.0 & 11.1 & 0.3 & 0.3 & 1.9 & 1.2 & 1.7 & 1.0 & \\
\hline Spondias mombin & & & 1.6 & & & & & 9.6 & 27.5 & 27.5 & & & & 4.0 & 29.0 & & & & & & & \\
\hline Stryphnodendron sp. & 5.2 & 5.2 & 4.1 & 5.1 & 2.4 & 4.9 & 2.1 & & & & 0.5 & 5.8 & 2.6 & & & & & & & & & \\
\hline Syzygium jambolanum & & & & & & & & & & & & & & & & 0.9 & & 3.8 & 2.0 & 2.4 & 2.9 & 0.3 \\
\hline Tabebuia serratifolia & & & & 2.6 & & & 0.3 & & & & 0.5 & 0.1 & & & & & & & & & & \\
\hline Tachigali tinctoria & & & & 5.0 & 3.7 & & & & & & 0.4 & 1.7 & 2.4 & & & & & & & & & \\
\hline Tapirira obtusa & & & & & & & & & & & & 3.0 & & & & & & & & & & \\
\hline Trema micrantha & 171.1 & 171.1 & 192.1 & & & & & 32.0 & 49.4 & 49.4 & 3.0 & 7.0 & & & & 9.0 & 4.4 & 55.5 & 25.3 & 55.0 & 22.9 & 5.5 \\
\hline Vismia antiscrophylla & & & & & & & & 1.6 & 4.5 & 4.5 & & & & & 2.4 & & & & & & & \\
\hline Vockisia sp. & & & & & & & 0.7 & & & & & & & & & & & & & & & \\
\hline Total & 259.4 & 259.4 & 4140.1 & 55.9 & 25.0 & 16.3 & 18.9 & 46.4 & 90.9 & 90.9 & 6.8 & 37.6 & 12.4 & 25.7 & 75.0 & 21.0 & 5.0 & 80.2 & 40.1 & 80.5 & 41.7 & 10.2 \\
\hline
\end{tabular}

Table A2. List of species sampled in active and natural regeneration sites, located south of Jirau Hydroelectric Reservoir, along the upper Madeira River.

\begin{tabular}{lcc}
\hline & Active Restoration & Natural Regeneration \\
\hline Achariaceae & & \\
\hline Lindackeria paludosa (Benth.) Gilg & $\mathrm{x}$ & \\
\hline Anacardiaceae & & \\
\hline Anacardium occidentale L. & $\mathrm{x}$ & \\
Mangifera indica L. & $\mathrm{x}$ & $\mathrm{x}$ \\
Spondias mombin L. & $\mathrm{x}$ & $\mathrm{x}$ \\
Tapirira guianensis Aubl. & $\mathrm{x}$ & $\mathrm{x}$ \\
Thyrsodium spruceanum Benth. & & $\mathrm{x}$ \\
\hline Annonaceae & & $\mathrm{x}$ \\
\hline Annona amazonica R.E.Fr. & & \\
Annona excellens R.E.Fr. & & $\mathrm{x}$ \\
Annona sp. 01 & $\mathrm{x}$ & $\mathrm{x}$ \\
Annona sp. 02 & $\mathrm{x}$ & $\mathrm{x}$ \\
Annonaceae 1 & & $\mathrm{x}$ \\
Bocageopsis multiflora (Mart.) R.E.Fr. & & $\mathrm{x}$ \\
Duguetia sp. & & $\mathrm{x}$ \\
Ephedranthus sp. & $\mathrm{x}$ & \\
Guatteria discolor R.E.Fr. & & \\
Guatteria sp. & & \\
Rollinia exsucca (DC. Ex Dunal) A. D.C. & & \\
\hline
\end{tabular}


Table A2. Cont.

\begin{tabular}{lcc}
\hline & Active Restoration & Natural Regeneration \\
\hline $\begin{array}{l}\text { Xylopia frutescens Aulb. } \\
\text { Xylopia sp. }\end{array}$ & $\mathrm{x}$ & $\mathrm{x}$ \\
\hline Apocynaceae & & \\
\hline Apocinaceae 01 & $\mathrm{x}$ & \\
$\quad \begin{array}{l}\text { Aspidosperma macrocarpon Mart. } \\
\text { Aspidosperma sp. }\end{array}$ & $\mathrm{x}$ & $\mathrm{x}$ \\
$\begin{array}{l}\text { Himatanthus articulatus (Vahl) Woodson } \\
\text { Himatanthus sucuuba (Spruce ex Müll. Arg.) }\end{array}$ & $\mathrm{x}$ & \\
$\begin{array}{l}\text { Woodson } \\
\text { Lacmellea gracilis (Müll.Arg.) Markgr. }\end{array}$ & & $\mathrm{x}$ \\
$\begin{array}{l}\text { Lacmellea sp. } \\
\text { Tabernaemontana coriacea Link ex Roem. \& }\end{array}$ & $\mathrm{x}$ & \\
Schult. & $\mathrm{x}$ & \\
\hline
\end{tabular}

\section{Araliaceae}

Schefflera morototoni (Aubl.) Maguire, Steyerm. \& Frodin

\begin{tabular}{|c|c|c|}
\hline \multicolumn{3}{|l|}{ Arecaceae } \\
\hline Astrocaryum aculeatum G. Mey. & $\mathrm{x}$ & \\
\hline Euterpe oleracea Mart. & $x$ & \\
\hline Euterpe precatoria Mart. & $x$ & \\
\hline \multicolumn{3}{|l|}{ Asteraceae } \\
\hline Vernonia sp. & $x$ & \\
\hline \multicolumn{3}{|l|}{ Bignoniaceae } \\
\hline $\begin{array}{l}\text { Cybistax sp. } \\
\text { Handroanthus impetiginosus (Mart. ex DC.) }\end{array}$ & & $\mathrm{x}$ \\
\hline $\begin{array}{l}\text { Mattos } \\
\text { Handroonthus serratifolius (A H Gentrv) }\end{array}$ & $x$ & \\
\hline $\begin{array}{l}\text { Handroanthus serratifolius (A.H.Gentry) } \\
\text { S.Grose }\end{array}$ & $x$ & $x$ \\
\hline Jacaranda copaia (Aubl.) D.Don & & $x$ \\
\hline Jacaranda sp. & $x$ & \\
\hline Tabebuia sp. & & $x$ \\
\hline Zeyheria tuberculosa (Vell.) Bureau & $x$ & \\
\hline \multicolumn{3}{|l|}{ Bixaceae } \\
\hline Bixa orellana $\mathrm{L}$. & $x$ & $\mathrm{x}$ \\
\hline Cochlospermum orinocense (Kunth) Steud. & $x$ & \\
\hline \multicolumn{3}{|l|}{ Burseraceae } \\
\hline Protium sp. & & $\mathrm{x}$ \\
\hline Protium amazonicum (Cuatrec.) Daly & $x$ & \\
\hline Protium unifoliolatum Engl. & $x$ & \\
\hline Tratinichia sp. & & $x$ \\
\hline Trattinnickia rhoifolia Willd. & & $x$ \\
\hline \multicolumn{3}{|l|}{ Cannabaceae } \\
\hline Trema micrantha (L.) Blume & $\mathrm{x}$ & $\mathrm{x}$ \\
\hline \multicolumn{3}{|l|}{ Chrysobalanaceae } \\
\hline Couepia sp. & & $\mathrm{x}$ \\
\hline Hirtella sp. & & $x$ \\
\hline Hirtella rodriguesii Prance & & $x$ \\
\hline Licania sp. & & $\mathrm{x}$ \\
\hline Licania latifolia Benth. ex Hook. f. & $x$ & \\
\hline Licania longistyla (Hook.f.) Fritsch & & $x$ \\
\hline
\end{tabular}


Table A2. Cont.

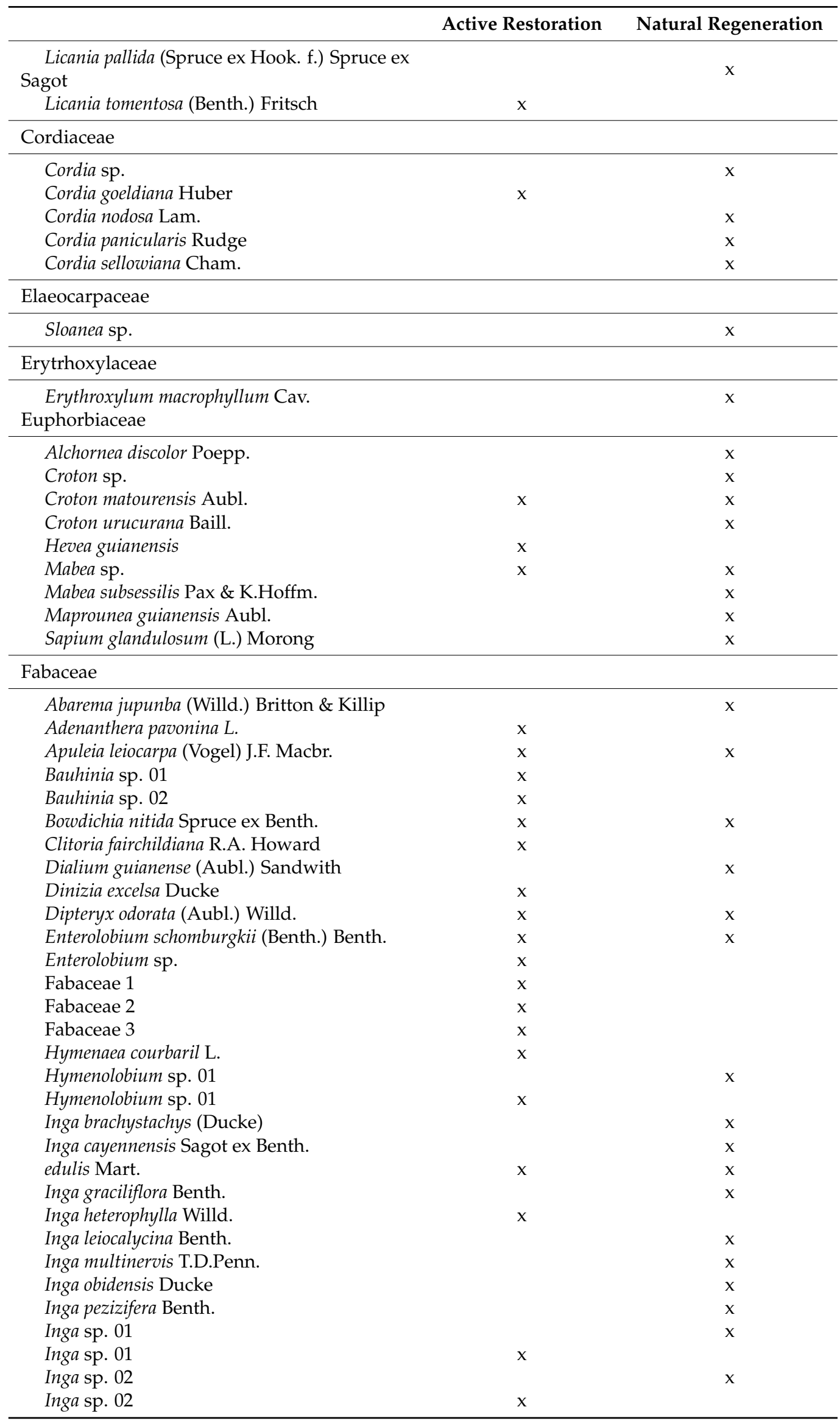


Table A2. Cont.

\begin{tabular}{|c|c|c|}
\hline & Active Restoration & Natural Regeneration \\
\hline Inga sp. 03 & $\mathrm{x}$ & \\
\hline Inga sp. 04 & $\mathrm{x}$ & \\
\hline Inga sp. 05 & $\mathrm{x}$ & \\
\hline Inga sp. 06 & $\mathrm{x}$ & \\
\hline Inga sp. 07 & $x$ & \\
\hline Inga thibaudiana DC. & & $x$ \\
\hline Inga vera Willd. & $x$ & \\
\hline Libidibia ferrea (Mart. ex Tul.) L.P. Queiroz & $\mathrm{x}$ & \\
\hline Ormosia grossa Rudd & $x$ & \\
\hline Parkia multijuga Benth. & $\mathrm{x}$ & \\
\hline Parkia pendula (Willd.) Benth. ex Walp. & $x$ & \\
\hline Platymiscium sp. & & $x$ \\
\hline Pterocarpus sp. & $\mathrm{x}$ & \\
\hline Pterocarpus amazonum (Mart. ex Benth.) & & \\
\hline Amshoff & $\mathrm{x}$ & \\
\hline Pterodon emarginatus Vogel & $x$ & \\
\hline Samanea tubulosa (Benth.) Barneby \& J.W. & & \\
\hline Grimes & $x$ & \\
\hline Schizolobium amazonicum Huber ex Ducke & $x$ & \\
\hline Senegalia sp. & $\mathrm{x}$ & \\
\hline Senna alata (L.) Roxb. & $x$ & \\
\hline Senna multijuga (Rich.) H.S. Irwin \& Barneby & $x$ & $x$ \\
\hline Stryphnodendron sp. & & $x$ \\
\hline Stryphnodendron duckeanum Occhioni & $x$ & \\
\hline Stryphnodendron pulcherrimum (Willd.) & & \\
\hline Hochr. & & $x$ \\
\hline Swartizia arborescens (Aubl.) Pittier & & $x$ \\
\hline Swartzia sp. & & $x$ \\
\hline Swartzia kuhlmannii Hoehne & $\mathrm{x}$ & \\
\hline Swartzia laurifolia Benth. & & $x$ \\
\hline Swartzia lucida R.S. Cowan & $x$ & $\mathrm{x}$ \\
\hline Swartzia corrugata Benth. & & $x$ \\
\hline Tachigali sp. & & $\mathrm{x}$ \\
\hline Tachigali chrysophylla (Poepp.) Zarucchi \& & & \\
\hline Herend. & & $x$ \\
\hline Tachigali tinctoria (Benth.) Zarucchi \& & & \\
\hline Herend. & $x$ & \\
\hline Vatairea fusca (Ducke) Ducke & $\mathrm{x}$ & \\
\hline Vatairea sericea (Ducke) Ducke & & $x$ \\
\hline $\begin{array}{l}\text { Zygia racemosa (Ducke) Barneby \& } \\
\text { J.W.Grimes }\end{array}$ & & $x$ \\
\hline \multicolumn{3}{|l|}{ Goupiaceae } \\
\hline Golpea sp. & & $\mathrm{x}$ \\
\hline Goupia glabra Aubl. & $x$ & $x$ \\
\hline \multicolumn{3}{|l|}{ Hypericaceae } \\
\hline Thyrsodium spruceanum Benth. & & $x$ \\
\hline Vismia cayennensis (Jacq.) Pers. & & $x$ \\
\hline Vismia gracilis Hieron. & $x$ & $x$ \\
\hline Vismia guianensis (Aubl.) Choisy & $\mathrm{x}$ & $x$ \\
\hline Vismia sandwithii Ewan & $x$ & $x$ \\
\hline \multicolumn{3}{|l|}{ Lacistemataceae } \\
\hline Lacistema grandifolium Schnizl. & & $x$ \\
\hline \multicolumn{3}{|l|}{ Lamiaceae } \\
\hline Vitex triflora Vahl & & $x$ \\
\hline Lauraceae & & \\
\hline
\end{tabular}


Table A2. Cont.

\begin{tabular}{|c|c|c|}
\hline & Active Restoration & Natural Regeneration \\
\hline Aniba sp. & & $x$ \\
\hline Lauraceae 1 & & $x$ \\
\hline Mezilaurus itauba (Meisn.) Taub. ex Mez & $x$ & \\
\hline Ocotea minor Vicent. & & $x$ \\
\hline Ocotea nigrescens Vicent. & & $x$ \\
\hline Ocotea sp. & $\mathrm{x}$ & \\
\hline \multicolumn{3}{|l|}{ Lechytidaceae } \\
\hline Couratari stellata A.C.Sm. & & $x$ \\
\hline Eschweilera coriacea (DC.) S.A.Mori & $x$ & $x$ \\
\hline Eschweilera laevicarpa S.A.Mori & & $\mathrm{x}$ \\
\hline Lecythis sp. & & $x$ \\
\hline Cariniana micrantha Ducke & $x$ & \\
\hline Couratari macrosperma A.C. Sm. & $x$ & \\
\hline \multicolumn{3}{|l|}{ Lythraceae } \\
\hline Physocalymma scaberrimum Pohl & $x$ & $x$ \\
\hline \multicolumn{3}{|l|}{ Malpighiaceae } \\
\hline Byrsonima sp. & & $x$ \\
\hline Byrsonima sp. 01 & $x$ & \\
\hline Byrsonima sp. 02 & $\mathrm{x}$ & \\
\hline \multicolumn{3}{|l|}{ Malvaceae } \\
\hline Apeiba tibourbou Aubl. & $x$ & $x$ \\
\hline Ceiba samauma (Mart.) K. Schum. & $\mathrm{x}$ & \\
\hline Eriotheca sp. & $x$ & \\
\hline Luehea sp. & & $x$ \\
\hline Ochroma pyramidale (Cav. ex Lam.) Urb. & $x$ & \\
\hline Pachira aquatica Aubl. & $\mathrm{x}$ & \\
\hline Pachira sp. & $x$ & \\
\hline Sterculia sp. & $x$ & \\
\hline Theobroma grandiflorum (Willd. ex Spreng.) & & \\
\hline K. Schum. & $\mathrm{X}$ & \\
\hline Theobroma speciosum Willd. ex Spreng. & $\mathrm{x}$ & $\mathrm{x}$ \\
\hline \multicolumn{3}{|l|}{ Melastomataceae } \\
\hline Belluccia grossularioides (L.) Triana & $x$ & $x$ \\
\hline Belluccia sp. & & $x$ \\
\hline Leandra cf dichotoma (Pav. ex D. Don) Cogn. & $x$ & \\
\hline Miconia argyrophylla DC. & & $\mathrm{x}$ \\
\hline Miconia biglandulosa Gleason & & $x$ \\
\hline Miconia cuspidata Naudin & $\mathrm{x}$ & $x$ \\
\hline Miconia elaeodendron (DC.) Naudin & & $x$ \\
\hline Miconia ferruginea (Desr.) DC. & & $x$ \\
\hline Miconia phanerostila Pilg. & & $x$ \\
\hline Miconia poeppigii Triana & & $x$ \\
\hline Miconia pyrifolia Naudin & $x$ & $x$ \\
\hline Miconia sp. 01 & & $x$ \\
\hline Miconia sp. 02 & & $\mathrm{x}$ \\
\hline Miconia sp. 03 & & $x$ \\
\hline Miconia sp. 04 & & $x$ \\
\hline Mouriri sp. & & $x$ \\
\hline Tococa subciliata (DC.) Triana & & $x$ \\
\hline \multicolumn{3}{|l|}{ Meliaceae } \\
\hline Carapa guianensis Aubl. & $x$ & \\
\hline Cedrela fissilis Vell. & $\mathrm{x}$ & \\
\hline
\end{tabular}


Table A2. Cont.

\begin{tabular}{|c|c|c|}
\hline & Active Restoration & Natural Regeneration \\
\hline \multicolumn{3}{|l|}{ Moraceae } \\
\hline Brosimum guianense (Aubl.) Huber & & $x$ \\
\hline Brosimum sp. & $\mathrm{x}$ & \\
\hline Ficus sphenophylla Standl. & $x$ & \\
\hline Machira sp. & & $x$ \\
\hline \multirow{2}{*}{\multicolumn{3}{|c|}{ C.C.Berg }} \\
\hline & & \\
\hline Moraceae 1 & & $x$ \\
\hline Perebea mollis (Poepp. \& Endl.) Huber & & $x$ \\
\hline Sorocea sp. & & $\mathrm{x}$ \\
\hline \multicolumn{3}{|l|}{ Muntingiaceae } \\
\hline Muntingia calabura L. & $x$ & \\
\hline \multicolumn{3}{|l|}{ Myristicaceae } \\
\hline Virola calophylla Warb. & & $x$ \\
\hline Virola cf. surinamensis (Rol. ex Rottb.) Warb. & $x$ & \\
\hline Virola multinervia Ducke & & $\mathrm{x}$ \\
\hline \multicolumn{3}{|l|}{ Myrtaceae } \\
\hline Caliptrantes sp. & & $x$ \\
\hline Eugenia patrisii Vahl & & $\mathrm{x}$ \\
\hline Eugenia sp. 01 & & $x$ \\
\hline Eugenia sp.02 & & $x$ \\
\hline Myrcia calycampa Amshoff & & $x$ \\
\hline Myrcia sp. 01 & & $x$ \\
\hline Myrcia sp. 01 & $x$ & \\
\hline Myrcia sp. 02 & $x$ & \\
\hline Myrcia sp. 02 & & $x$ \\
\hline Myrcia sp. 03 & & $x$ \\
\hline Myrcia sp. 04 & & $x$ \\
\hline Myrcia subsericea A. Gray & & $x$ \\
\hline Myrtaceae 1 & & $x$ \\
\hline Myrtaceae 1 & $x$ & \\
\hline Myrtaceae 2 & $x$ & \\
\hline Myrtaceae 3 & $x$ & \\
\hline Myrtaceae 4 & $x$ & \\
\hline Myrtaceae 5 & $x$ & \\
\hline Psidium guajava L. & $x$ & $x$ \\
\hline Psidium sp. & & $x$ \\
\hline Syzygium cumini (L.) Skeels & $x$ & $x$ \\
\hline Syzygium jambos (L.) Alston & $x$ & \\
\hline Non identified & & $x$ \\
\hline N. I. 01 & & $x$ \\
\hline N. I. 02 & & $x$ \\
\hline N. I. 01 & $x$ & \\
\hline N. I. 02 & $x$ & \\
\hline N. I. 03 & $x$ & \\
\hline N. I. 04 & $\mathrm{x}$ & \\
\hline N. I. 05 & $x$ & \\
\hline N. I. 06 & $x$ & \\
\hline N. I. 07 & $x$ & \\
\hline N. I. 08 & $x$ & \\
\hline N. I. 09 & $x$ & \\
\hline N. I. 10 & $x$ & \\
\hline N. I. 11 & $x$ & \\
\hline N. I. 12 & $x$ & \\
\hline N. I. 13 & $x$ & \\
\hline
\end{tabular}


Table A2. Cont.

\begin{tabular}{lcc}
\hline & Active Restoration & Natural Regeneration \\
\hline N. I. 14 & $\mathrm{x}$ & \\
N. I. 15 & $\mathrm{x}$ & \\
N. I. 16 & $\mathrm{x}$ & \\
\hline Nyctaginaceae & $\mathrm{x}$ \\
\hline Neea theifera Oerst. & $\mathrm{x}$ \\
\hline Ochnaceae & $\mathrm{x}$ \\
\hline $\begin{array}{l}\text { Ouratea sp. } \\
\text { Ouratea odora Engl. }\end{array}$ & $\mathrm{x}$ \\
\hline Olacaceae & $\mathrm{x}$ \\
\hline Minquartia guianensis Aubl. & \\
\hline Pentaphylacaceae & $\mathrm{x}$ \\
\hline Ternstroemia dentata (Aubl.) Sw. & \\
\hline Phyllanthaceae & \\
\hline Richeria grandis Vah & \\
\hline
\end{tabular}

\begin{tabular}{|c|c|c|}
\hline \multicolumn{3}{|l|}{ Piperaceae } \\
\hline Piper aduncum L. & $x$ & \\
\hline \multicolumn{3}{|l|}{ Primulaceae } \\
\hline Cybianthus sp. & & $\mathrm{x}$ \\
\hline \multicolumn{3}{|l|}{ Quiinaceae } \\
\hline Lacunaria macrosthachya (Tul.) A.C Sm. & & $\mathrm{x}$ \\
\hline \multicolumn{3}{|l|}{ Rhizophoraceae } \\
\hline Sterigmapetalum obovatum Kuhlm. & & $x$ \\
\hline \multicolumn{3}{|l|}{ Rubiaceae } \\
\hline Alibertia sp. & & $\mathrm{x}$ \\
\hline Capirona decorticans Spruce & & $x$ \\
\hline Cordiera concolor (Cham.) Kuntze & $x$ & \\
\hline Duroia sp. & & $x$ \\
\hline Duroia longiflora Ducke & & $x$ \\
\hline Ferdinandusa hirsuta Standl. & & $x$ \\
\hline Genipa americana L. & $x$ & \\
\hline Isertia hypoleuca Benth. & $x$ & $x$ \\
\hline Psychotria sp. & & $x$ \\
\hline Richeria grandis Vah & & $x$ \\
\hline Rubiaceae 1 & & $x$ \\
\hline Rubiaceae 1 & $x$ & \\
\hline Warszewiczia coccinea (Vahl) Klotzsch & & $\mathrm{x}$ \\
\hline \multicolumn{3}{|l|}{ Rutaceae } \\
\hline Citrus aurantifolia Swingle & $x$ & \\
\hline Citrus sp. & & $x$ \\
\hline Dictyoloma vandellianum A. Juss. & & $x$ \\
\hline Nycticalanthus sp. & & $x$ \\
\hline Zanthoxylum rhoifolium Lam. & $\mathrm{x}$ & \\
\hline \multicolumn{3}{|l|}{ Salicaceae } \\
\hline Casearia duckeana Sleumer & & $x$ \\
\hline Casearia grandiflora Cambess. & & $x$ \\
\hline Casearia javitensis Kunth & $x$ & $x$ \\
\hline Casearia negrensis Eichler & & $x$ \\
\hline Laetia procera (Poepp.) Eichler & & $x$ \\
\hline
\end{tabular}


Table A2. Cont.

\begin{tabular}{|c|c|c|}
\hline & Active Restoration & Natural Regeneration \\
\hline Ryania speciosa Vahl & & $\mathrm{x}$ \\
\hline \multicolumn{3}{|l|}{ Sapindaceae } \\
\hline Cupania hispida Radlk. & & $x$ \\
\hline Cupania rubiginosa (Poir.) Radlk. & $x$ & \\
\hline Matayba sp. & & $\mathrm{x}$ \\
\hline Matayba arborescens (Aubl.) Radlk. & & $\mathrm{x}$ \\
\hline Talisia sp. & & $\mathrm{x}$ \\
\hline Toulicia guianensis Aubl. & & $x$ \\
\hline \multicolumn{3}{|l|}{ Sapotaceae } \\
\hline Pouteria caimito (Ruiz \& Pav.) Radlk. & $x$ & \\
\hline Pouteria sp. & & $\mathrm{x}$ \\
\hline \multicolumn{3}{|l|}{ Simaroubaceae } \\
\hline Homalolepis sp. & $x$ & \\
\hline Quassia amara L. & $\mathrm{x}$ & \\
\hline Simarouba amara Aubl. & $\mathrm{x}$ & $x$ \\
\hline Simarouba versicolor A. St.-Hil. & $\mathrm{x}$ & \\
\hline Pouteria sp. & $\mathrm{x}$ & \\
\hline \multicolumn{3}{|l|}{ Simaroubaceae } \\
\hline Siparuna sp. & & $x$ \\
\hline Siparuna guianensis Aubl. & & $\mathrm{x}$ \\
\hline \multicolumn{3}{|l|}{ Solanaceae } \\
\hline Solanum lycocarpum A. St.-Hil. & $\mathrm{x}$ & \\
\hline Solanum spp. & $x$ & \\
\hline Solanum subinerme Jacq. & & $\mathrm{x}$ \\
\hline Solanum viarum Dunal & $\mathrm{x}$ & \\
\hline \multicolumn{3}{|l|}{ Urticaceae } \\
\hline Cecropia distachya Huber & $x$ & $x$ \\
\hline Cecropia membranacea Trécul & $x$ & \\
\hline Cecropia purpurascens C.C. Berg & $\mathrm{x}$ & $x$ \\
\hline Cecropia sciadophylla Mart. & & $x$ \\
\hline Cecropia sp. & $x$ & \\
\hline \multicolumn{3}{|l|}{ Vochysiaceae } \\
\hline Qualea paraensis Ducke & & $x$ \\
\hline Rouisteranea sp. & & $x$ \\
\hline Ruizterania albiflora (Warm.) Marc.-Berti & & $x$ \\
\hline Ruizterania retusa (Spruce ex Warm.) & & \\
\hline Marc.-Berti & $x$ & \\
\hline
\end{tabular}

\section{References}

1. Chazdon, R.L.; Uriarte, M. Natural regeneration in the context of large-scale forest and landscape restoration in the tropics. Biotropica 2016, 48, 709-715. [CrossRef]

2. Chazdon, R.L.; Guariguata, M.R. Natural regeneration as a tool for large-scale forest restoration in the tropics: Prospects and challenges. Biotropica 2016, 48, 716-730. [CrossRef]

3. Holl, K.D.; Aide, T.M. When and where to actively restore ecosystems? Ecol. Manag. 2011, 261, 1558-1563. [CrossRef]

4. Poorter, L.; Bongers, F.; Aide, T.M.; Zambrano, A.M.A.; Balvanera, P.; Becknell, J.M.; Boukili, V.; Brancalion, P.H.; Broadbent, E.N.; Chazdon, R.L.; et al. Biomass resilience of Neotropical secondary forests. Nature 2016, 530, 211-214. [CrossRef]

5. Rezende, G.M.; Vieira, D.L.M. Forest restoration in southern Amazonia: Soil preparation triggers natural regeneration. Ecol. Manag. 2019, 433, 93-104. [CrossRef]

6. Jakovac, C.C.; Bongers, F.; Kuyper, T.; Mesquita, R.C.G.; Pena-Claros, M. Land use as a filter for species composition in Amazonian secondary forests. J. Veg. Sci. 2016, 27, 1104-1116. [CrossRef] 
7. Mesquita, R.D.C.G.; Massoca, P.E.D.S.; Jakovac, C.C.; Bentos, T.V.; Williamson, G.B. Amazon Rain Forest Succession: Stochasticity or Land-Use Legacy? BioScience 2015, 65, 849-861. [CrossRef]

8. $\quad$ Freitas, M.G.; Rodrigues, S.B.; Campos-Filho, E.M.; do Carmo, G.H.P.; da Veiga, J.M.; Junqueira, R.G.P.; Vieira, D.L.M. Evaluating the success of direct seeding for tropical forest restoration over ten years. Ecol. Manag. 2019, 438, 224-232. [CrossRef]

9. VanWey, L.K.; Spera, S.; de Sa, R.; Mahr, D.; Mustard, J.F. Socioeconomic development and agricultural intensification in Mato Grosso. Philos. Trans. R. Soc. B Biol. Sci. 2013, 368, 20120168. [CrossRef]

10. Durigan, G.; Guerin, N.; da Costa, J.N.M.N. Ecological restoration of Xingu Basin headwaters: Motivations, engagement, challenges and perspectives. Philos. Trans. R. Soc. B Biol. Sci. 2013, 368, 20120165. [CrossRef]

11. Corbin, J.D.; Holl, K.D. Applied nucleation as a forest restoration strategy. For. Ecol. Manag. 2012, 265, 37-46. [CrossRef]

12. Rodrigues, S.B.; Freitas, M.G.; Campos-Filho, E.M.; do Carmo, G.H.P.; da Veiga, J.M.; Junqueira, R.P.; Vieira, D.L.M. Direct seeded and colonizing species guarantee successful early restoration of South Amazon forests. For. Ecol. Manag. 2019, 451, 117559. [CrossRef]

13. Sansevero, J.B.B.; Prieto, P.V.; de Moraes, L.F.D.; Rodrigues, P.J.F.P. Natural regeneration in plantations of native trees in lowland Brazilian Atlantic forest: Community structure, diversity, and dispersal syndromes. Restor. Ecol. 2011, 19, 379-389. [CrossRef]

14. César, R.G.; Moreno, V.S.; Coletta, G.D.; Chazdon, R.L.; Ferraz, S.F.B.; de Almeida, D.R.A.; Brancalion, P.H.S. Early ecological outcomes of natural regeneration and tree plantations for restoring agricultural landscapes. Ecol. Appl. 2018, 28, 373-384. [CrossRef]

15. Weidlich, E.W.A.; Flórido, F.G.; Sorrini, T.B.; Brancalion, P.H.S. Controlling invasive plant species in ecological restoration: A global review. J. Appl. Ecol. 2020, 57, 1806-1817. [CrossRef]

16. Camargo, J.L.C.; Ferraz, I.D.K.; Imakawa, A.M. Rehabilitation of degraded areas of central Amazonia using direct sowing of forest tree seeds. Restor. Ecol. 2002, 10, 636-644. [CrossRef]

17. Cochrane, T.T.; Cochrane, T.A. Amazon Forest and Savanna Lands: A Guide to the Climates, Vegetation, Landscapes and Soils of Central Tropical South America; CreateSpace: Scotts Valley, CA, USA, 2010.

18. Rocha, G.P.E.; Vieira, D.L.M.; Simon, M.F. Fast natural regeneration in abandoned pastures in southern Amazonia. Ecol. Manag. 2016, 370, 93-101. [CrossRef]

19. Kishy, I.; Reis, F.; Solidera, D.; Solidera, D.; Borges, A.; Rezende, G.M.; Vieira, D.L.M. How a company is restoring its 3,000 hectares of forest liability and supporting local communities. In Forest Landscape Restoration and Social Opportunities in the Tropical World; Pinto, S.R.R., Santos, F.C., Prescott, C., Eds.; CEPAN: Recife, Brazil, 2020; pp. 249-258.

20. Gehring, C.; Park, S.; Denich, M. Close relationship between diameters at $30 \mathrm{~cm}$ height and at breast height (DBH). Acta Amaz. 2008, 38, 71-76. [CrossRef]

21. Legendre, P.; Anderson, M.J. Distance-based redundancy analysis: Testing multispecies responses in multifactorial ecological experiments. Ecol. Monogr. 1999, 69, 1-24. [CrossRef]

22. Crouzeilles, R.; Curran, M. Which landscape size best predicts the influence of forest cover on restoration success? A global meta-analysis on the scale of effect. J. Appl. Ecol. 2016, 53, 440-448. [CrossRef]

23. Shoo, L.P.; Freebody, K.; Kanowski, J.; Catterall, C.P. Slow recovery of tropical old-field rainforest regrowth and the value and limitations of active restoration. Conserv. Biol. 2015, 30, 121-132. [CrossRef]

24. Suganuma, M.S.; Durigan, G. Indicators of restoration success in riparian tropical forests using multiple reference ecosystems. Restor. Ecol. 2015, 23, 238-251. [CrossRef]

25. Williamson, G.B.; Bentos, T.V.; Longworth, J.B.; Mesquita, R.C.G. Convergence and divergence in alternative successional pathways in Central Amazonia. Plant Ecol. Divers. 2012, 7, 341-348. [CrossRef]

26. Norden, N.; Mesquita, R.C.G.; Bentos, T.V.; Chazdon, R.L.; Williamson, G.B. Contrasting community compensatory trends in alternative successional pathways in central Amazonia. Oikos 2011, 120, 143-151. [CrossRef]

27. Uhl, C.; Buschbacher, R.; Serrao, E.A.S. Abandoned Pastures in Eastern Amazonia. I. Patterns of Plant Succession. J. Ecol. 1988, 76, 663-681. [CrossRef]

28. Silveira, M.; Trevelin, L.; Port-Carvalho, M.; Godoi, S.; Mandetta, E.N.; Cruz-Neto, A.P. Frugivory by phyllostomid bats (Mammalia: Chiroptera) in a restored area in Southeast Brazil. Acta Oecologica 2011, 37, 31-36. [CrossRef]

29. Heinrich, V.H.; Dalagnol, R.; Cassol, H.L.; Rosan, T.M.; de Almeida, C.T.; Junior, C.H.S.; Campanharo, W.A.; House, J.I.; Sitch, S.; Hales, T.C.; et al. Large carbon sink potential of secondary forests in the Brazilian Amazon to mitigate climate change. Nat. Commun. 2021, 12, 1785. [CrossRef]

30. Gardon, F.R.; dos Santos, R.F.; Rodrigues, R.R. Brazil's forest restoration, biomass and carbon stocks: A critical review of the knowledge gaps. For. Ecol. Manag. 2020, 462, 117972. [CrossRef]

31. Giudice Badari, C.; Bernardini, L.E.; de Almeida, D.R.A.; Brancalion, P.H.S.; César, R.G.; Gutierrez, V.; Chazdon, R.L.; Gomes, H.B.; Viani, R.A.G. Ecological outcomes of agroforests and restoration 15 years after planting. Restor. Ecol. 2020, 28, 1135-1144. [CrossRef]

32. Rajão, R.; Soares-Filho, B.; Nunes, F.; Börner, J.; Machado, L.; Assis, D.; Oliveira, A.; Pinto, L.; Ribeiro, V.; Rausch, L.; et al. The rotten apples of Brazil's agribusiness. Science 2020, 369, 246-248. [CrossRef] [PubMed] 